PiJIES: Pedagogik Journal of Islamic Elementary School

October 2018, Vol.1, No.2, hal.105-118

ISSN(P): 2356-1483; ISSN(E):2615-3904

(C)2018 PGMI IAIN Palopo. http://ejournal-iainpalopo.ac.id/PiJIES

\title{
MENINGKATKAN HASIL BELAJAR SISWA DENGAN MODEL COOPERATIVE \\ LEARNING TIPE JIGSAW PADA SISWA KELAS V \\ SD NEGERI 16 KOTA PAREPARE
}

\author{
Nur Rahmatan Mursalin \\ Program Studi Pendidikan Guru Madrsah Idtidaiyah \\ Institut Agama Islam DDI Polman \\ Jl. Gatot Soebroto Kel. Madatte Kec. Polewali \\ Email : nurrahmatan99@gmail.com
}

\begin{abstract}
Abstrack
The initial idea of this study was the low learning outcomes of students in science lessons, especially green plant material. This is because teachers are less creative in using teaching methods and models that can help students in learning. The main problem in this study is how to improve student learning outcomes in green plants through jigsaw cooperative learning in class V SD Negeri 16 Kota Parepare. This study aims to determine the improvement of student learning outcomes by using a jigsaw type cooperative learning model for grade V students of SD Negeri 16 Kota Parepare. The procedure for activities in research includes planning, action, observation and reflection. Subjects in this study were teachers and students of class V SD Negeri 16 Kota Parepare TA. 2010/2011 with a total of 22 students with details of 14 men and 8 women. Data collection techniques used are observation, test, and documentation techniques. The results showed that student learning outcomes in green plants with the use of jigsaw cooperative learning method in cycle I were categorized as poor $(K)$ then increased in cycle II with categories of Enough (C), and in cycle III categorized as Good (B). Thus, the use of jigsaw cooperative learning method can improve the learning outcomes of grade $V$ students of SD Negeri 16 Kota Parepare.
\end{abstract}

Keywords: science learning, cooperative learning type JIGSAW, learning outcomes

\begin{abstract}
Abstrak
Ide awal penelitian ini adalah rendahnya hasil belajar siswa pada pelajaran IPA khususnya materi tumbuhan hijau. Hal ini disebabkan karena guru kurang kreatif dalam menggunakan metode dan model mengajar yang dapat membantu siswa dalam pembelajaran. Masalah utama dalam penelitian ini adalah bagaimana meningkatkan hasil belajar siswa pada tumbuhan hijau melalui
\end{abstract}


106 | Nur Rahmatan

cooperative learning tipe jigsaw di kelas V SD Negeri 16 Kota Parepare. Penelitian ini bertujuan untuk mengetahui peningkatan hasil belajar siswa dengan menggunakan model cooperative learning tipe jigsaw pada siswa kelas $\mathrm{V}$ SD Negeri 16 Kota Parepare. Prosedur kegiatan dalam penelitian meliputi perencanaan, pelaksanaan tindakan, observasi dan refleksi. Subjek dalam penelitian ini adalah guru dan siswa kelas V SD Negeri 16 Kota Parepare TA. 2010/2011 dengan jumlah murid sebanyak 22 dengan rincian 14 laki-laki dan 8 perempuan. Teknik pengumpulan data yang digunakan adalah teknik observasi, tes, dan dokumentasi. Hasil penelitian menunjukkan bahwa hasil belajar siswa pada tumbuhan hijau dengan penggunaan metode cooperative learning tipe jigsaw pada siklus I dikategorikan kurang (K) kemudian meningkat pada siklus II dengan kategori Cukup (C), dan pada siklus III dikategorikan Baik (B). Dengan demikian, penggunaan metode cooperative learning tipe jigsaw dapat meningkatkan hasil belajar siswa kelas V SD Negeri 16 kota Parepare.

Kata kunci : pembelajaran IPA, cooperative learning tipe JIGSAW, hasil belajar

\section{PENDAHULUAN}

Guru merupakan salah satu pelaku dalam proses pendidikan yang dituntut dapat memiliki kemampuan dalam merencanakan dan melaksanakan proses belajar mengajar. Kemampuan ini akan menjadi bekal guru dalam melaksanakan tugas dan tanggung jawabnya sebagai seorang pengajar. Oleh karena itu, pendidikan menjadi proses jangka panjang yang memerlukan perencanaan matang, meliputi: mengkoordinasikan unsur-unsur tujuan, bahan pengajaran, kegiatan belajar mengajar, metode dan alat bantu mengajar serta penilaian (Suwardi:2017).

Peranan siswa atau peserta didik dalam proses belajar mengajar turut menentukan keberhasilan dari proses tersebut, sehingga siswa perlu diberikan motivasi agar tumbuh minat yang besar dalam hatinya untuk terlibat langsung dalam proses belajar mengajar untuk memperoleh hasil sesuai dengan harapan. Sesuai dengan UU No. 20 tahun 2003 tentang sistem pendidikan nasional, pasal 3 menyatakan bahwa Pendidikan nasional berfungsi mengembangkan kemampuan dan membentuk watak serta peradaban bangsa yang bermartabat 
dalam rangka mencerdaskan kehidupan bangsa, bertujuan untuk berkembangnya potensi peserta didik agar menjadi manusia yang bertakwa kepada Tuhan YME, berakhlak mulia, sehat, berilmu, cakap, kreatif, mandiri, dan menjadi warga Negara yang demokratis serta bertanggung jawab.

Peningkatan mutu pendidikan sangat ditentukan oleh guru sebagai pendidik dalam pencapaian tujuan pendidikan yang diharapkan. Dengan kata lain guru menempati titik sentral pendidikan. Agar guru mampu menunaikan tugasnya dengan baik, maka terlebih dahulu harus memahami hal-hal yang berhubungan dengan proses belajar mengajar seperti halnya proses pendidikan pada umumnya. Untuk mencapai tujuan ini peran guru sangat menentukan. Peranan dan kompetensi guru dalam proses belajar mengajar meliputi banyak hal sebagaimana yang dikemukakan oleh (Adam dan Decey:2010) antara lain guru sebagai pengajar, pemimpin kelas, pembimbing, pengatur lingkungan, partisipan, ekspeditor, perencana, supervisor, motivator, dan konselor. Dengan demikian peranan guru yang sangat penting adalah mengaktifkan dan mengefisienkan proses belajar di sekolah termasuk dalam penggunaan metode mengajar yang sesuai.

Penggunaan metode mengajar yang tepat, merupakan suatu alternatif mengatasi masalah rendahnya daya serap siswa terhadap pelajaran IPA. Ilmu pengetahuan alam berhubungan dengan cara mencari tahu tentang alam secara sistematis, sehingga IPA bukan hanya penguasaan kumpulan pengetahuan yang berupa fakta-fakta, konsep-konsep, atau prinsip-prinsip saja tetapi juga merupakan suatu proses penemuan Pemilihan metode pembelajaran IPA khususnya dan ilmu pengetahuan pada umumnya memerlukan suatu metode pengajaran yang meninjau dari segi keefektifan, keefesienan dan kecocokannya dengan karakteristik materi pelajaran serta keadaan siswa yang meliputi kemampuan, kecepatan belajar, minat, waktu yang dimiliki dan keadaan sosial ekonomi siswa sebagai obyek (Suwardi:2007).

Kurangnya hasil belajar siswa disebabkan oleh beberapa faktor diantaranya yaitu tingkat penguasaan siswa terhadap materi pelajaran IPA 
108 | Nur Rahmatan

sangat rendah, dan penggunaan metode yang kurang tepat dan efesien. Melihat kondisi tersebut,maka penelitiber upaya mencari metode yang dianggap tepat dan dapat meningkatkan kemampuan siswa yaitu dengan metode diskusi kelompok kecil. Namun, ternyata metode ini masih kurang efektif pula karena dalam kerja kelompok hanya sebagian siswa yang aktif sedangkan siswa lain membicarakan hal yang tidak berhubungan dengan materi pelajaran. Untuk mengatasi hal tersebut di atas maka di upayakan para pengajar yang profesional dan bertnggung jawab serta dapat menetukan metode yang tepat sesuai dengan tingkat pemahaman anak didik. Metode yang paling baik dalam mengajar adalah metode yang cocok dan sesuai dengan si pembawa metode yakni guru (Usman:2000). Hal lain yang harus diperhatikan guru dalam memilih metode itu dengan tingkat pencapaian tujuan pembelajaran dan keadaan siswa.

Oleh sebab itu, dalam penelitian ini bertujuan untuk membangkitkan motivasi siswa agar aktivitas dalam proses pembelajaran berhasil dengan baik. Sugesti-sugesti positif dapat menstimulus siswa untuk mampu menyelesaikan tugas yang dihadapi (Thaha \& Rustan, 2017). Suasana belajar yang diharapkan adalah menjadikan siswa sebagai subjek yang berupaya menggali dan memecahkan masalah sendiri dari suatu konsep yang dipelajari. Situasi belajar yang diharapkan disini adalah siswa yang lebih banyak berperan aktif dan kreatif. Tujuan pembelajaran kooperatif tipe jigsaw adalah menciptakan situasi dimana keberhasilan individu ditentukan atau dipengaruhi oleh keberhasilan kelompoknya (Slavin:1995).

Berdasarkan uraian di atas, maka peneliti tertarik untuk mengambil judul penelitian yakni “ Meningkatkan Hasil Belajar Siswa Pada Materi Tumbuhan Hijau Melalui Model Cooperative Learning Tipe Jigsaw di kelas V SD Negeri 16 Parepare".

\section{KERANGKA TEORITIS}

Pendidikan ilmu pengetahuan alam atau sains merupakan pendidikan bidang studi dengan alam semesta serta segala proses yang terjadi di dalamnya 
sebagai objeknya (Warsiman, 2015:13). IPA merupakan salah satu mata pelajaran pokok dalam kurikulum pendidikan di Indonesia, termasuk pada jenjang sekolah dasar. Susanto (2013:166), Ilmu Pengetahuan Alam adalah usaha manusia dalam memahami alam semesta melalui pengamatan yang tepat pada sasaran, serta menggunakan prosedur, dan dijelaskan dengan penalaran sehingga mendapatkan suatu kesimpulan. IPA berhubungan dengan cara mencari tahu tentang alam secara sistematis, sehingga bukan hanya penguasaan kumpulan pengetahuan yang berupa fakta, konsep, atau prinsip saja tetapi juga merupakan suatu proses penemuan (BSNP, 2006).

Dari uraian tentang pengertian IPA tersebut, dapat disimpulkan bahwa ilmu pengetahuan alam merupakan pembelajaran berdasarkan pada prinsip-prinsip, proses yang dapat menumbuhkan sikap ilmiah siswa terhadap konsep-konsep IPA melalui pengamatan, diskusi dan penyelidikan sederhana. Pendidikan IPA diharapkan dapat menjadi wahana bagi peserta didik untuk mempelajari diri sendiri dan alam sekitar dan alam sekitarnya, serta prospek pengembangan lebih lanjut dalam menerapkannya di dalam kehidupan sehari-hari. Menurut Susanto (2013:169) "Sikap ilmiah siswa dalam pembelajaran IPA dapat dikembangkan melalui kegiatan diskusi, percobaan, observasi, simulasi, atau kegiatan proyek di lapangan".

Pembelajaran IPA di SD memberi kesempatan untuk memupuk rasa ingin tahu siswa secara alamiah. Hal ini akan membantu siswa mengembangkan kemampuan bertanya dan mencari jawaban berdasarkan bukti serta mengembangkan cara berpikir ilmiah. IPA tidak hanya merupakan kumpulan pengetahuan atau kumpulan fakta, konsep, prinsip, atau teori semata. Tetapi IPA juga menyangkut tentang cara kerja, cara berpikir dan cara memecahkan masalah. Berdasarkan Kurikulum Tingkat Satuan Pendidikan (KTSP), BSNP (2011:13) menyatakan mata pelajaran IPA di SD bertujuan agar siswa memiliki kemampuan sebagai berikut:

a. Memperoleh keyakinan terhadap kebesaran Tuhan Yang Maha Esa berdasarkan keberadaan, keindahan, dan keteraturan alam ciptaannya.

b. Mengembangkan pengetahuan dan pemahaman konsep-konsep IPA yang bermanfaat dan dapat diterapkan dalam kehidupan sehari-hari.

c. Mengembangkan rasa ingin tahu, sikap positif dan kesadaran tentang adanya hubungan yang saling mempengaruhi antara IPA, lingkungan, teknologi, dan masyarakat.

d. Mengembangkan keterampilan proses untuk menyelidiki alam sekitar, memecahkan masalah, dan membuat keputusan. 
e. Meningkatkan kecerdasan untuk berperan serta dalam memelihara, menjaga, dan melestarikan lingkungan alam.

f. Meningkkatkan kesadaran untuk menghargai alam dan segala keteraturannya sebagai salah satu ciptaan Tuhan.

g. Memperoleh bekal pengetahuan, konsep, dan keterampilan IPA sebagai dasar untuk melanjutkan pendidikan ke jenjang yang lebih tinggi.

Cooperative mengandung pengertian bekerja sama dalam mencapai tujuan bersama. Dalam kegiatan kooperatif terjadi pencapaian tujuan secara bersama-sama yang sifatnya merata dan menguntungkan setiap anggotanya. Pengertian pembelajaran kooperatif adalah pemanfaatan kelompok kecil dalam proses pembelajaran yang memungkinkan kerja sama dalam menuntaskan permasalahan. Sehubungan dengan pengertian tersebut, Slavin menyatakan bahwa Pembelajaran Kooperatif adalah suatu model pembelajaran dimana pebelajar belajar dan bekerja sama dalam kelompok-kelompok kecil secara kolaboratif yang anggotanya terdiri dari 4 sampai 6 orang, dengan struktur kelompok yang bersifat heterogen. Selanjutnya dikatakan pula, keberhasilan belajar dari kelompok tergantung pada kemampuan dan aktivitas anggota kelompok, baik secara individual maupun secara kelompok. Pembelajaran kooperatif juga dapat diartikan sebagai suatu srtuktur tugas bersama dalam suasana kebersamaan diantara sesama anggota kelompok.

Tujuan pembelajaran kooperatif adalah menciptakan situasi dimana keberhasilan individu ditentukan atau dipengaruhi oleh keberhasilan kelompoknya, hal ini dikemukakan oleh Slavin dalam Suradi dan Djadir bahwa model pembelajaran kooperatif dikembangkan untuk mencapai empat tujuan pembelajaran yang dirangkum sebagai 1) hasil belajar akademik, 2) penerimaan terhadap perbedaan individu, 3) pengembangan keterampilan sosial, dam 4) lingkungan belajar dan sistem pengelolaan.

Soli Abimanyu (2009), mengemukakan bahwa ciri-ciri atau karakteristik dari pembelajaran kooperatif adalah sebagai berikut :

a) Kelompok dibentuk dari pebelajar yang memiliki kemampuan tinggi, sedang, dan rendah.

b) Jika memungkinkan setiap anggota kelompok berasal dari ras, budaya, suku, jenis kelamin, yang berbeda.

c) Pebelajar belajar dalam kelompok secara kooperatif untuk menuntaskan materi.

d) Penghargaan lebih berorientasi kelompok daripada individu.

Menurut Slavin (1995) menyatakan bahwa kelebihan pembelajaran kooperatif tipe JIGSAW yakni sebagai berikut : 
1) Dapat mengembangkan tingkah laku kooperatif dan hubungan yang lebih baik antar siswa.

2) Dapat mengembangkan kemampuan akademis siswa.

3) Dapat memacu terbentuknya ide baru dan memperkaya perkembangan intelektual siswa.

Adapun kelemahan pembelajaran kooperatif tipe JIGSAW menurut Roy Killen yakni sebagai berikut :

a) Prinsip utama pola pembelajaran ini adalah "Peer teaching ", pembelajaran oleh teman sendiri ini akan menjadi kendala karena perbedaan persepsi dalam memahami suatu konsep yang akan didiskusikan bersama dengan siswa lain.Dalam hal ini pengawasan guru menjadi hal muktlak diperlukan,agar jangan sampai terjadi " Missconception ".

b) Dirasa sulit menyakinkan siswa untuk mampu berdiskusi menyampaikan materi kepada teman, jika siswa tidak punya rasa percaya diri.

c) Rekod siswa tentang nilai, kepribadian, perhatian siswa harus sudah dimiliki oleh pendidik dan ini biasanya membutuhkan waktu yang cukup lama untuk mengenali tipe-tipe siswa dalam kelas tersebut.

d) Awal penggunaan metode ini biasanya sulit dikendalikan,butuh waktu yang cukup dan persiapan yang matang sebelum model pembelajarn ini bisa berjalan dengan baik.

Adapun Langkah-langkah pembelajaran kooperatif tipe sebagai berikut:

1) Siswa dibagi dalam kelompok kecil yang disebut kelompok asal, beranggotakan 4-5 orang. Setiap siswa diberi nomor misalnya 1, 2, 3, 4, dan 5.

2) Membagi wacana / tugas sesuai dengan materi yang diajarkan. Masingmasing siswa dalam kelompok assal mendapat wacana atau tugas yang berbeda, nomor yang sama mendapat tugas yang sama pada masing-masing kelompok.

3) Kumpulkan masing-masing siswa yang memiliki wacana/ tugas yang sama dalam satu kelompok sehingga jumlah kelompok ahli sama dengan jumlah wacana/ tugas yang telah dipersiapkan guru.

4) Dalam kelompok ahli ini ditugaskan agar siswa belajar bersama untuk menjadi ahli sesuai dengan wacana/ tugas yang menjadi tanggung jawabnya.

5) Tugaskan bagi semua anggota kelompok ahli untuk memahami dan dapat menyampaikan informasi tentang hasil dari wacana/ tugas yang telah dipahami kepada kelompok kooperatif (kelompok asal).

6) Apabila tugas telah selesai dikerjakan dalam kelompok ahli masing-masing siswa kembali ke kelompok asal. 
112 | Nur Rahmatan

7) Beri kesempatan secara bergiliran masing-masing siswa untuk menyampaikan hasil dari tugas di kelompok ahli.

8) Bila kelompok sudah menyelesaikan tugasnya secara keseluruhan,masingmasing kelompok menyampaikan hasilnya dan guru memberi klarifikasi.

Hasil belajar adalah pola-pola perbuatan, nilai-nilai, pengertian, sikap, apresiasi, abilitas, dan keterampilan yang diterima oleh murid untuk memberi kepuasan pada kebutuhannya yang berguna serta bermakna baginya yang dilengkapi dengan serangkaian pengalaman yang dapat dipersamakan dengan pertimbangan yang baik (Hamalik:2001). Proses belajar dan hasil belajar dipengaruhi oleh dua faktor, yaitu faktor yang berasal dari dalam diri anak ( internal ) dan faktor yang berasal dari luar diri anak (eksternal). Faktor internal antara lain adalah faktor psikologi, sedangkan faktor eksternal antara lain adalah faktor lingkungan dan faktor instrumental.

\section{METODE PENELITIAN}

Penelitian ini menggunakan pendekatan kualiitatif. Pendekatan ini dipilih agar dapat mendeskripsikan aktivitas siswa dan guru dalam pelaksanaan tindakan pembelajaran. Pendekatan kualitatif mempunyai ciri-ciri yaitu : (1) Latar ilmiah, (2) Manusia sebagai alat, (3) Metode kualitatif, (4) Analisis atau secara induktif, (5) Teori dan dasar, (6) Deskriptif, (7) Lebih mementingkan proses daripada hasil, (8) Adanya batas yang ditentukan oleh fokus, (9) Adanya kriteria khusus untuk keabsahan data, (10) Desain yang bersifat sementara, (11) Hasil penelitian dirunding dan sisepakati bersama (Moeloeng,2007:172).

Jenis penelitian ini adalah Penelitian Tindakan Kelas ( PTK ) dimana proses penelitian dalam tindakan ini merupakan sebuah siklus atau proses daur ulang yang terdiri dari empat aspek fundamental. Diawali dari aspek mengembangkan perencanaan kemudian melakukan tindakan perencanaan, observasi/pengamatan terhadap tindakan, evaluasi dan diakhiri dengan melakukan refleksi (Kemmis dan Taggar dalam Arikunto,2008:16). Model penelitian yang dilakukan adalah Classroom action research yang dilakukan secara kolaborasi anatara peneliti, teman sejawat dan guru kelas V. Penggunaan sistem ini bertujuan meningkatkan hasil pembelajaran IPA di kelas V SD dengan rangcangan penelitian berdaur ulang (siklus). Secara garis besar prosedur pelaksanaannya dapat dilakukan melalui 5 tahap yaitu : Perencanaan (planning), Pelaksanaan Tindakan (action), Pengamatan (observasi) dan refleksi (reflection).

Pengumpulan data dilakukan dengan teknik observasi, wawacara, hasil pembelajaran catatan lapangan, dan dokumentasi, Berikut uraiannya sebagai berikut : 


\section{1) Observasi}

Pengamatan dilakukan pada saat proses pembelajaran berlangsung. Pelaksanaan pengamatan ini dalam bentuk mencatat peristiwa-peristiwa yang dianggap penting dalam pelaksanaan tindakan,

2) Wawancara

Wawancara dilakukan untuk memperoleh gambaran tentang pelaksanaan pembelajaran dengan menggunakan metode cooperative learning tipe jigsaw. Wawacara ini ditujukan kepada kepala sekolah dan guru kelas V SDN 16 Parepare.

3) Hasil Pembelajaran

Data yang diperoleh dari hasil pembelajaran adalah data berupa hasil kerja siswa yang diperlukan untuk mengetahui tingkat keberhasilan dalam proses pembelajaran.

4) Catatan Lapangan

Catatan lapangan atau catatan harian digunakan sebagai refleksi peneliti terhadap tindakan praktisi berupa gagasan atau pendapat pada saat pembelajaran berlangsung dengan fokus pada prilaku atau aktivitas guru dan siswa dalam pembelajaran.

5) Dokumentasi

Data yang diperoleh dari hasil dokumentasi ada;ah berupa aktivitas proses pembelajaran siswa yang diperoleh melalui hasil evaluasi dan tes.

Analisis data yang digunakan dalam penelitian ini adalah analisis data deskriptif kualitatif. Analisis ini dimaksudkan untuk mendeskripsikan segala gejala-gejala yang didapatkan dalam penelitian. Pengelolaan dan analisis data dilakukan secara refleksi, partisipasi dan kolaborasi terhadap perkataan tindakan dan hasil dokumen. Sedangkan tahap validasi data dilakukan melalui tekni Triangulasi berikut ini peneliti mencek kebenaran data dikonsultasikan bersama guru, peneliti, dan teman sejawat melalui langkah-langkah sebagai berikut : (1) Member check, mencek kebenaran dan kesahihan data berdasarkan temuan peneliti dan mengkonfirmasikan dengan sumber data (guru kelas) melalui diskusi pada setiap akhir pelaksanaan tindakan, (2) Audi trail, mencek kebenaran hasil penelitian dan mendiskusikan dengan teman sejawat yang dianggap mengetahui pengetahuan penelitian tindakan kelas. Analisis data merupakan cara merangkum data secara akurat dan benar. Data yang dianalisis adalah aspek siswa terdiri atas aktivitas proses dan hasil. Data proses pembelajaran ditafsirkan dengan menggunakan rumus sebagai berikut:

Rumus : Jumlah yang muncul X $100 \%$ 
114 | Nur Rahmatan

Jumlah yang seharusnya

Analisis data hasil tulisan siswa ditafsirkan berdasarkan kecendrungan pencapaian skor setiap langkah-langkah yaitu LKS (Lembar Kerja Siswa) dan tes formatif dengan skor ideal masing-masing adalah 100. Data diberi kualifikasi berdasarkan kecendrungan seperti dalam Tabel 1 berikut ini :

Tabel 1. Kualifikasi kriteria keberhasilan tindakan (guru dan siswa)

\begin{tabular}{ll}
\hline Taraf Keberhasilan & Kualifikasi \\
\hline $85 \%-100 \%$ & Sangat Baik ( SB ) \\
$70 \%-84 \%$ & Baik ( B ) \\
$55 \%-69 \%$ & Cukup ( C ) \\
$46 \%-54 \%$ & Kurang ( K) \\
$0 \%-45 \%$ & Sangat Kurang ( SK) \\
\hline
\end{tabular}

Sumber : Mill (2009) disitasi oleh Khalik

Mengetahui tingkat keberhasilan proses dan hasil belajar digunakan skala dalam rentang nilai 85-100 dinyatakan Sangat Baik (SB), rentang 70-84 dinyatakan Baik (B), rentang 55-69 dinyatakan Cukup (C), rentang 46-54 dinyatakan Kurang (K) dan rentang 0 - 45 dinyatakan Sangat Kurang (SK). Guna menentukan validasi data dilakukan trianulasi teman sejawat.

1. Indikator proses, tindakan dikategorikan berhasil bila minimal $80 \%$ pelaksanaannya telah sesuai dengan pembelajaran IPA dengan menggunakan model cooperative learning tipe Jigsaw dalam meningkatkan aktivitas siswa dalam bekerja kelompok.

2. Indikator tindakan dikatakan berhasil bila minimal $80 \%$ siswa telah mencapai nilai \pm 75 .

\section{HASIL PENELITIAN DAN PEMBAHASAN}

Pada deskripsi penelitian ini akan dibahas hasil penelitian dengan menggunakan model cooperative learning tipe Jigsaw yang diawali dengan pra tindakan. Hal ini dilakukan untuk mengetahui kelemahan-kelemahan siswa dalam belajar IPA mengenai Tumbuhan Hijau, sebelum dilakukannya proses 
pembelajaran dengan menggunakan model cooperative learning tipe Jigsaw. Pelaksanaan pra tindakan dilakukan satu kali pertemuan.

Penelitian ini diawali dengan kegiatan observasi awal di SDN 16 Parepare pada tanggal 14 Februari 2011 yang dilanjutkan dengan wawancara singkat dengan kepala sekolah tentang maksud dan tujuan penelitian tindakan kelas, sekaligus mengadakan wawancara dengan guru kelas tentang mata pelajaran IPA khususnya materi Tumbuhan Hijau.

Hasil observasi dan wawancara awal pada tanggal 14 Februari 2011 kepada kepala sekolah tentang proses pembelajaran di kelas, terlihat bahwa pembelajaran masih didominasi oleh metode/model pembelajaran tradisional oleh guru. Dengan demikian maka guru dalam menyajikan materi pelajaran Tumbuhan Hijau menghadapi masalah kurang mampunya siswa dan kurang siapnya siswa dalam belajar IPA serta kurangnya pengetahuan yang dimiliki terhadap metode/model pembelajaran apa yang harus diterapkan dalam meningkatkan hasil belajar tersebut.

Oleh sebab itu untuk mengetahui kemampuan siswa kelas V SDN 16 Parepare maka pada tanggal 21 Februari 2011 diadakan tes awal. Tes awal yang telah dikerjakan siswa kemudian dianalisis oleh peneliti dibantu oleh guru kelas $\mathrm{V}$ dengan tujuan mengetahui hasil belajar siswa terhadap materi Tumbuhan Hijau. Berdasarkan hasil analisis peneliti terhadap hasil tes awal masih banyak ditemukan siswa yang melakukan kesalahan dalam menyelesaikan tes awal. Dari tes tersebut secara klasikal menunjukkan bahwa kemampuan siswa masih kurang sehingga dikategorikan sangat rendah karena dari keseluruhan jumlah siswa sebanyak 22 orang tidak ada siswa yang memperoleh nilai dengan kategori Sangat Baik (SB), namun demikian hanya 14 orang yang masuk kategori Cukup (C), yang masuk kategori Kurang (K) sebanyak 4 orang dan yang masuk kategori Sangat Kurang (SK) sebanyak 3 orang sehingga memperoleh nilai rata-rata yaitu 54,4. Adapun data tentang hasil tes awal dapat dilihat pada lampiran 14 halaman 102.

Kondisi dan situasi seperti ini perlu diperbaiki dan disempurnakan sehingga kelemahan-kelemahan siswa dalam pembelajaran IPA khususnya materi Tumbuhan Hijau dapat teratasi dan meningkatkan hasil belajar siswa. Salah satu metode yang dianggap cocok untuk menjawab masalah tersebut adalah melakukan Penelitian Tindakan Kelas (PTK) dengan menggunakan metode Cooperative Learning Tipe Jigsaw dimana dalam pelaksanaanya siswa akan dibagi menjadi beberapa kelompok (asal dan ahli) dalam menyelesaikan tugas yang diberikan bersama dengan anggota kelompok. 
Selanjutnya peneliti menyusun rencana pembelajaran untuk penelitian ini yang direncanakan dalam 3 siklus. Setelah itu mengkonsultasikan kepada guru kelas $\mathrm{V}$ guna penyempurnaan dari rencana pembelajaran yang telah dibuat. Peneliti mempelajari rencana tersebut sebelum melakukan tindakan setiap siklus. Selanjutnya peneliti menyerahkan lembar observasi yang telah disusun sesuai dengan model Cooperative Learning Tipe Jigsaw untuk diketahui dan dipelajari sebagai dasar untuk melakukan pengamatan selama penelitian berlangsung. Kegiatan pengumpulan data dalam penelitian ini dilaksanakan sejak tanggal 14 Februari 2011, adapun jadwalnya dapat dilihat pada lampiran I halaman 71.

Dalam model cooperative learning tipe Jigsaw, siswa ditempatkan dalam kelompok belajar yang beranggotakan 4-5 orang merupakan campuran akademik yang berbeda, sehingga dalam setiap kelompok terdapat siswa dengan kemampuan yang pandai, sedang, dan kurang. Dalam proses siklus I, siswa ditugaskan melakukan diskusi sesuai dengan materi yang telah ditentukan sesuai dengan rencana pelaksanaan pembelajaran yang telah disusun yakni materi tentang Tumbuhan Hijau. Dalam mengawali pembelajaran tentang tumbuhan hijau, terlebih dahulu melakukan tanya jawab yaitu menyebutkan beberapa jenis tumbuhan yang ada di lingkungan sekolah maupun di rumah. Siswa mengamati artikel yang dibagikan oleh guru (peneliti) dan mengisi lembar kerja siswa. Namun dalam hal ini masih terdapat kekurangan, dimana kekurangan tersebut berasal dari guru (peneliti) yang menyampaikan tujuan pembelajaran kurang jelas, dan kurang memotivasi siswa.

Sedangkan kekurangan yang berasal dari siswa yaitu saat guru (peneliti) menyampaikan cara melakukan diskusi siswa tidak memperhatikan dengan baik dan banyak memperhatikan kelompok yang lain sehingga mereka tidak memperhatikan penjelasan guru dengan baik, selain itu siswa masih ragu untuk menanyakan hal-hal yang kurang dimengerti sehubungan dengan materi pelajaran. Sehingga guru (peneliti) tidak mengetahui dengan jelas letak kesalahan siswa.

Berdasarkan hasil observasi dan hasil penelitian ditemukan bahwa penggunaan metode cooperative learning tipe Jigsaw untuk meningkatkan hasil belajar tumbuhan hijau pada siswa kelas V SDN 16 Parepare mulai dari tes awal, siklus I, siklus II dan siklus III menunjukkan peningkatan yang signifikan. Hal ini terbukti dari nilai rata-rata yang dicapai pada hasil belajar siswa selama proses diskusi kelompok berlangsung pada siklus I siswa yang memperoleh nilai $>75$ sebanyak 10 orang siswa atau 33,18 \% dan memperoleh nilai rata-rata 64,54 ini termasuk pada kategori cukup (C), pada siklus II siswa yang memperoleh nilai 
> 75 sebanyak 19 orang siswa atau 64,09 \% dengan nilai rata-rata 72,27 nilai ini masuk kategori Baik (B) dan pada siklus III siswa yang memperoleh nilai > 75 sebanyak 20 orang siswa atau $84 \%$ serta nilai rata-rata yang diperoleh adalah 81,81 hal ini sudah menunjukkan bahwa indikator keberhasilan yang ditetapkan sudah tercapai.

Hal ini menunjukkan bahwa betapa pentingnya penggunaan metode cooperative learning tipe Jigsaw tersebut dapat meningkatkan kreativitas, keaktifan, motivasi serta kemampuan siswa untuk menerima pelajaran dengan mudah dimengerti.

\section{PENUTUP}

Dari keseluruhan paparan data hasil penelitian dan pembahasan yang terdapat pada Bab IV, maka dapat ditarik kesimpulan : Berdasarkan temuan pada pelaksanaan tindakan maka dapat disimpulkan bahwa metode Cooperative Learning tipe Jigsaw dapat meningkatkan hasil belajar siswa kelas V SDN 16 Parepare. Hal ini disebabkan karena guru (peneliti) sudah membimbing dan mengarahkan siswa serta memotivasi siswa agar berusaha dan aktif dalam berdiskusi.

Dari hasil observasi yang menunjukkan data hasil belajar siswa adalah sebagai berikut : pada siklus I menujukkan bahwa rata-rata siswa memperoleh nilai dengan kategori Cukup (C), namun siswa yang memperoleh nilai > 75 adalah sebanyak 10 orang siswa atau 33,18\% dan memperoleh nilai rata-rata 64,54 data ini masih sangat jauh dari indikator keberhasilan yang ditetapkan yakni minimal 80\% siswa yang memperoleh nilai $>75$, sedangkan data penelitian hasil belajar tumbuhan hijau dengan menggunakan metode Jigsaw pada siswa kelas V disiklus II yakni sebanyak 19 orang siswa atau 64,09\% memperoleh nilai $>75$ dengan nilai rata-rata 72,27 nilai ini masuk kategori Baik (B) dan pada siklus III siswa yang memperoleh nilai $>75$ sebanyak 20 orang siswa atau $84 \%$ serta nilai rata-rata yang diperoleh adalah 81,81 hal ini sudah menunjukkan bahwa indikator keberhasilan yang ditetapkan sudah tercapai .

\section{DAFTAR PUSTAKA}

Abimanyu, Soli. 2009. Pendidikan dan Latihan Profesi Guru. Makassar : UNM. Azmiyati, Choiril. 2008. IPA 5 Salingtemas. Jakarta : Erlangga 
118 | Nur Rahmatan

Direktorat Pendidikan Dasar. 2000. Konsep IPA Terpilih di SD. Jakarta : Departemen Pendidikan dan Kebudayaan.

Hamalik, Oemar. 2001a.Proses Belajar Mengajar.Jakarta : PT Bumi Aksara.

Menteri Pendidikan Nasional Republik Indonesia Nomor 22 Tahun 2006 tentang

Standar Isi Untuk Satuan Pendidikan Dasar dan Menengah. Jakarta.

Moleong, Lexy J. 2007. Metodologi Penelitian Kualitatif: Bandung: Rosdakarya.

Purwanto, Ngalaim. 2007. Psikologi Pendidikan. Jakarta : PT Remaja Rosdakarya.

Putra, Rizema. 2012. Desain Belajar Mengajar Kreatif Berbasis Sains. Jogjakarta:Diva Press.

Samatowa, Usman. 2010. Pembelajaran IPA di Sekolah Dasar. Jakarta:Indeks.

Suharsimi,dkk. 2008. Penelitian Tindakan Kelas. Jakarta : Sinar Grafika.

Suprijono, Agus. 2009. Cooperative Learning Teori dan Aplikasi PAIKEM.

Surabaya : Pustaka Pelajar.

Suwardi. 2007. Manajemen Pembelajaran. Salatiga : PT Temprina.

Thaha, H., \& Rustan, E. (2017). Orientasi Religiusitas dan Efikasi Diri dalam

Hubungannya dengan Kebermaknaan Pendidikan Agama Islam pada

Mahasiswa IAIN Palopo. Studi Agama Dan Masyarakat, 13(2), 163-179.

https://doi.org/10.23971/jsam.v13i2.551

Tim Pengembang Ilmu Pendidikan. 2007. Ilmu dan Aplikasi Pendidikan. Bandung

: PT Impreal Bhakti Utama.

Undang - Undang Republik Indonesia Nomor 20 Tahun 2003 tentang Sistem Pendidikan Nasional. Jakarta : Depdiknas.

Usman, Uzer. 2007. Menjadi Guru Profesional. Bandung : PT Remaja Rosdakarya. Walgito, Bimo. 2002. Pengantar Psikologi Umum. Yogyakarta : Andi. 